\title{
The Effect of Sterilization on Size and Shape of Fat Globules in Model Processed Cheese Samples
}

\author{
B. TREMLOVÁ ${ }^{1}$, P. ŠTARHA ${ }^{2}$, F. BUŇKA ${ }^{3}$, Z. GISTINGROVÁ ${ }^{1}$, J. HRABË $^{3}$ \\ University of Veterinary and Pharmaceutical Sciences Brno ${ }^{1)}$ \\ Brno University of Technology 2) \\ Tomáš Bata University in Zlín ${ }^{3)}$
}

Received November 3, 2005

Accepted May 11, 2006

\begin{abstract}
Tremlová B., P. Štarha, F. Buňka, Z. Gistingrová, J. Hrabě: The Effect of Sterilization on Size and Shape of Fat Globules in Model Processed Cheese Samples. Acta vet. Brno 2006, 75: 419-425.

Model cheese samples from 4 independent productions were heat sterilized $\left(117^{\circ} \mathrm{C}, 20\right.$ minutes $)$ after the melting process and packing with an aim to prolong their durability. The objective of the study was to assess changes in the size and shape of fat globules due to heat sterilization by using image analysis methods. The study included a selection of suitable methods of preparation mounts, taking microphotographs and making overlays for automatic processing of photographs by image analyser, ascertaining parameters to determine the size and shape of fat globules and statistical analysis of results obtained.

The results of the experiment suggest that changes in shape of fat globules due to heat sterilization are not unequivocal. We found that the size of fat globules was significantly increased $(p<0.01)$ due to heat sterilization $\left(117^{\circ} \mathrm{C}, 20 \mathrm{~min}\right)$, and the shares of small fat globules (up to $500 \mu \mathrm{m}^{2}$, or $100 \mu^{2}$ ) in the samples of heat sterilized processed cheese were decreased. The results imply that the image analysis method is very useful when assessing the effect of technological process on the quality of processed cheese quality.
\end{abstract}

Processed cheese, heat sterilization, fat, image analysis, histochemical analysis

Image analysis methods have become a useful tool for the evaluation of various defects and quantitative variables of food materials. The measurement of different parameters using image analysis is associated with important sensoric and technological properties of food materials when it comes to food samples. The study by Holcomb et al. (1992) showed that on the basis of rheological and structural examinations of dairy products, functional properties of products can be estimated by evaluating their microscopic structure. Also in the study of dairy products, image analysis methods are used, often associated with the microscopic and sensoric evaluation.

Caccamo et al. (2004) compared the formation of gases in different kinds of cheese, focusing on the measurement of gas holes size in the section area. These methods provide a considerable potential for the evaluation of processed cheese quality, mainly in association with sensoric analysis. Thus, it is possible to estimate structural changes due to different heat treatments that affect the compact nature of protein matrix or fat particle distribution, which are the factors unequivocally influencing the texture of processed cheeses (Caric and Kaláb 1997; Guinee 2003).

Processed cheeses are manufactured by heating a mixture of various kinds of natural cheeses at different stages of maturity, with emulsifying agents under partial vacuum and constant stirring, until a homogenous blend of required properties is achieved. Other raw materials, both dairy and non-dairy ones, can be added to the blend of natural cheeses.

\footnotetext{
Address for correspondence:

Doc. MVDr. Bohuslava Tremlová, Ph.D

Department of Vegetable Foodstuffs and Plant Production

University of Veterinary and Pharmaceutical Sciences Brno

Palackého 1-3

61242 Brno, Czech Republic
}

Phone: +420 541562700

E-mail : tremlovab@vfu.cz

http://www.vfu.cz/acta-vet/actavet.htm 
Phosphates, polyphosphates, and, to a smaller extent, citrates are used as emulsifying agents (Caric and Kaláb 1997).

When soldiers cannot be provided with warm food (separation from the unit, combat, etc.), they can receive so-called combat rations. There are special requirements for minimum shelf life of food components of combat rations. The minimum shelf life of these was determined as 24 months at the ambient temperature (Standardization Agreement No. 2937, 2001). The combat rations can also be used by members of the integrated rescue system when in operation. Combat rations of NATO armies (e.g. U.S.A., Germany and France) contain processed cheese.

Processed cheese is a typical non-acid food. It is usually melted under $100{ }^{\circ} \mathrm{C}$ (Bylund 1995). The temperature can only kill vegetative forms of microorganisms but not bacterial spores that may cause degradation of the product (Mafart et al. 2001). One of the ways to achieve a shelf life of 24 months in processed cheeses is heat sterilization.

Yoon and McCarthy (2003) studied properties of processed cheese samples by using a combined method of magnetic resonance and image analysis with different melting conditions. In the study by Wang and Sun (2002), a computerized system of image analysis was used for the evaluation of cheese properties, relevant for the melting process. For the comparison, two kinds of cheese were chosen (Cheddar and Mozzarella) and various combinations of time and temperature were used. Wang and Sun (2003) used the image analysis for Cheddar and Mozzarella cheeses once again. This time the purpose was to determine colour changes in these two cheeses during the heating. When the course of browning process was evaluated, it was found that correlations between time and temperature defined as browning factor are different. The method used proved to be an efficient and objective tool for monitoring colour changes in cheese.

The properties of processed cheese are influenced by many factors such as the composition, kind and degree of maturity of the cheese used, as well as of the added components, the nature and amount of emulsifiers, $\mathrm{pH}$ and manufacturing process parameters (Marchesseau et al. 1997). Some researchers (Raval and Mistry 1999) stated that milk fat is a very important component of processed cheeses since it influences their properties, for instance spreadability.

In the study performed by Klostermeyer and Buchheim (1988), samples withdrawn at different stages of the melting process were investigated. Using electron microscopy, they studied the microstructure and compared the structure of protein matrix and its changes during the melting processes. They used two samples of processed cheese, made under the same conditions, the only difference being the rotation rate of the stirring device (lower and higher $(10 \times)$ rotation rate). Differences in the size of fat globules were obvious, and much smaller at a higher rotation rate. There were some differences within the protein matrix, too, and the samples processed under the higher rotation rate of the melting boiler showed locally markedly larger protein particles.

Sutheerawattananonda et al. (1997) studied the effect of heat treatment duration on fat particle distribution and the degree of emulsification of processed cheese samples, using various kinds of emulsifying agent. They measured the size and shape of fat particles in model samples of processed cheese, using fluorescence microscopy and image analysis. Different heat treatments and the presence of emulsifying agents significantly influenced the shape and size of fat globules. Results showed that there were not any truly round or circular globules in the cutaway view. For the examination by the fluorescence microscope, the samples were stained with Nile blue. For the light microscopy, methods using the Sudan group stains, Oil red and osmium tetroxide are most commonly used. The rate and intensity of staining depend on the stain concentration (Flint 1994).

A wad et al. (2002) compared the texture and microstructure of cheese samples processed with different emulsifying agents. Different manufacturing process conditions influenced 
the number and size (diameter) of fat globules. The size (diameter) ranged from $16.9 \pm 0.5$ to $87.5 \pm 7.9 \mu \mathrm{m}$ in different samples. Marchesseau et al. (1997) evaluated the effect of $\mathrm{pH}$ value on the microstructure of processed cheeses, mainly in terms of changes in the protein matrix. They found fat globules of 2 - $3 \mu \mathrm{m}$ in diameter.

Bowland and Foegeding (2001) monitored the effect of different processing conditions on rheological properties and properties of the lipid phase in model samples. Using microscopic examination and image analysis they found that percentages of the cross-sectional area took up by fat in model samples ranged from $31.0 \pm 4.9$ to $41.5 \pm 6.5 \%$. The size (diameter) of fat globules ranged between $3.53 \pm 0.49$ and $5.45 \pm 0.84 \mu \mathrm{m}$.

Many reported results suggest that image analysis is suitable for quantitative evaluation of images obtained by microscopic examination (e.g. Bijker et al. 1983; Hildebrandt and Hirst 1985; Rao et al. 1989; Heertje and Leunis 1997; Palka and Daun 1999). Depending on the aim of examination, variables to be measured are chosen. The aim of examination is often to ascertain the size, shape or colour of objects (Zikmundová 1996). The basis for processing and evaluation of a microscope image is a sufficient contrast enabling the analyser to identify objects correctly. This depends both on the staining method chosen and the quality of mount (Tremlová and Štarha 2002).

The objective of the present study was to apply the method of image analysis of microscope mount to assess the effect of heat sterilization treatment $\left(117^{\circ} \mathrm{C}, 20 \mathrm{~min}\right)$ on the size and shape of fat globules in model processed cheeses.

\section{Materials and Methods}

Four groups of processed cheese were analysed. The values declared were dry matter (38\% w/w) and fat on dry matter basis $(45 \% \mathrm{w} / \mathrm{w})$. Each group of processed cheese was manufactured separately from other groups, but using the same technological procedure. The processed cheeses were made from a mixture of natural cheeses, butter, cottage cheese, water and emulsifying agents. The melt was filled in laminated aluminium containers. After closing the containers, each group of samples was divided into two parts. The first half of samples from all the groups was cooled down to $10{ }^{\circ} \mathrm{C}$ within 2 hours (hereinafter referred to as "non-sterilized processed cheeses" $\mathrm{N}$ ); the second half was subjected to sterilization treatment. Heat sterilization was performed by the sterilizer LUBECA at $117{ }^{\circ} \mathrm{C}$ for 20 minutes; then the samples in the sterilizer were cooled down to $25^{\circ} \mathrm{C}$ (hereinafter referred to as "sterilized processed cheeses" - S). The samples were stored in the refrigerator at $8 \pm 2{ }^{\circ} \mathrm{C}$, until the analyses were carried out. Each time, 3 packages of non-sterilized and 3 packages of sterilized processed cheese were analysed in each group.

For the image analysis, microscope mounts were made and stained with Oil red (Plate V, Fig. 1). The mounts were examined by the microscope Jenaval $250-\mathrm{CF}$, using 32 -fold magnification. Microphotographs were taken by the digital camera Olympus C 4000. The documentation for each sample included about 40 pictures, and for image analysis, 16 microphotographs were chosen from each picture and individually processed by the image analysis software ACC (Image Structure and Object Analyse, v. 6.0). The processing of pictures was based on the scheme presented in the study by Tremlová and Štarha (2002) and included the following steps:

1 Insertion of a measure for the magnification used

2 Creation of an overlay for fat globules, based on the colour and brightness of standard samples selected

3 Determination of variables (area of objects, $\mathrm{SF}=$ shape factor, sizes of half axes $\mathrm{A}$ and $\mathrm{B}$ )

4 Analysis (automatic, using an overlay, manual corrections).

The evaluation of shape was based on the values of the size of half axes of the Legendre ellipse which approximates the object measured, and the shape coefficient calculated. The changes in shape were evaluated by comparing mean values of shape coefficient $t_{\mathrm{ab}}$ for different samples which was determined according to the equation (1). When the shape of an object resembles a circle, the value of shape coefficient approaches $k+\infty$, when the shape of an object resembles a line, the shape coefficient value approaches $\mathrm{k}-\infty$. A basic property of the Legendre ellipse is that its area is the same as that of the object analysed.

$$
\mathrm{t}_{\mathrm{ab}}=-\ln \left(\frac{a^{6}+b^{6}}{a^{3} b^{3}}-2\right)
$$

a: length of the major half axis

b: length of the secondary half axis

ln: hyperbolic logarithm. 
The size of fat globules was determined as a value obtained by measuring their area.

Student's $t$-test at a significance level of $\alpha=0.01$ was used to evaluate whether there were any statistically significant differences in the shape and size of fat globules between the samples of non-sterilized processed cheeses and sterilized processed cheese. In order to simplify the situation, we anticipated normal distribution of shape coefficient $t_{\mathrm{a}, \mathrm{b}}$ values.

For comparison, the non-parametric Wilcoxon test (Agresti 1987) was used to assesses whether differences in the shape and size of fat globules between the samples of non-sterilized processed cheese and sterilized processed cheese were significant or not. The change in fat globule size distribution was also evaluated by calculating percentages of small objects before and after the heat treatment. The Microsoft EXCEL software was used to perform the calculations.

\section{Results}

Table 1 gives basic results found by image analysis of samples. For each sample, the same number of pictures (16) was analysed and total image area was the same for all the samples, too.

Table 1. Summarized results of the examinations

\begin{tabular}{|c|c|c|c|c|c|c|c|c|}
\hline \multirow[t]{2}{*}{ Group } & \multicolumn{2}{|c|}{ I } & \multicolumn{2}{|c|}{ II } & \multicolumn{2}{|c|}{ III } & \multicolumn{2}{|c|}{ IV } \\
\hline & $\mathrm{N}$ & $\mathrm{S}$ & $\mathrm{N}$ & $\mathrm{S}$ & $\mathrm{N}$ & $\mathrm{S}$ & $\mathrm{N}$ & $\mathrm{S}$ \\
\hline \multicolumn{9}{|l|}{ Parameter } \\
\hline No. of pictures & & & & 16 & & & & \\
\hline \multicolumn{9}{|c|}{ Globule area } \\
\hline$\sum \mathrm{mm}^{2}$ & 0.73 & 1.16 & 0.72 & 0.55 & 1.75 & 2.21 & 4.64 & 0.59 \\
\hline $\begin{array}{r}\text { Smallest globule } \\
\mu \mathrm{m}^{2}\end{array}$ & 10.5 & 36.7 & 10.5 & 10.5 & 10.5 & 10.5 & 12.2 & 10.5 \\
\hline $\begin{array}{r}\text { Largest globule } \\
\mu \mathrm{m}^{2}\end{array}$ & 8070.9 & 27936.4 & 17446.8 & 3104.3 & 8657.0 & 42677.2 & 2320.8 & 13504.8 \\
\hline Globule count & 1671 & 2179 & 1875 & 1515 & 3564 & 3353 & 2288 & 2193 \\
\hline
\end{tabular}

$\mathrm{N}$ : non-sterilized, S: sterilized

Table 2 presents general results of shape evaluation of different groups of processed cheeses. The statistical analysis (Student's $t$-test) results show $(\mathrm{A}=0.01)$ that sterilization of processed cheese does not cause unequivocal changes in the shape of fat globules. Due to the sterilization treatment, in groups I and IV the values of the shape coefficient decreased, in group III the shape coefficient values increased, and in group II the shape coefficient was not influenced by the sterilization treatment used.

Table 2. Values of shape coefficient tab for the non-sterilized and sterilized processed cheeses of the four groups under investigation (mean, S.D.)

\begin{tabular}{|c|c|c|c|c|}
\hline \multirow{2}{*}{$\begin{array}{c}\text { Processed } \\
\text { cheese group }\end{array}$} & \multirow{2}{*}{$\begin{array}{l}\text { Processed } \\
\text { cheese type }\end{array}$} & \multicolumn{2}{|c|}{ Shape coefficient $t_{a b}$} & \multirow{2}{*}{$\begin{array}{c}\text { No. of fat globules } \\
\text { measured }\end{array}$} \\
\hline & & Mean & S.D. & \\
\hline \multirow[t]{2}{*}{ I } & Non-sterilized & 1.54 & 1.62 & 1671 \\
\hline & Sterilized & 0.71 & 1.64 & 2179 \\
\hline \multirow[t]{2}{*}{ II } & Non-sterilized & 1.06 & 1.73 & 1875 \\
\hline & Sterilized & 0.97 & 1.70 & 1515 \\
\hline \multirow[t]{2}{*}{ III } & Non-sterilized & 1.14 & 1.64 & 3564 \\
\hline & Sterilized & 1.39 & 1.67 & 3353 \\
\hline \multirow[t]{2}{*}{ IV } & Non-sterilized & 1.03 & 1.53 & 2288 \\
\hline & Sterilized & 0.67 & 1.78 & 2193 \\
\hline
\end{tabular}


Table 3 gives mean values and standard deviations (S.D.) of the fat globule area in individual samples. In the three groups (I, III and IV) of non-sterilized processed cheeses, mean values of fat globule area were significantly lower than mean values in sterilized processed cheeses $(p<0.01)$, which means that in non- sterilized processed cheeses an average size (assessed by area) of fat globules is lower than in sterilized processed cheeses. Only in group II, no significant differences were found.

Table 3. Mean fat globule area for the non-sterilized and sterilized processed cheeses of the four groups under investigation (mean, S.D.)

\begin{tabular}{|c|c|c|c|c|}
\hline \multirow{2}{*}{$\begin{array}{c}\text { Processed } \\
\text { cheese group }\end{array}$} & \multirow{2}{*}{$\begin{array}{l}\text { Processed } \\
\text { cheese type }\end{array}$} & \multicolumn{2}{|c|}{ Fat globule area $\left(\mu \mathrm{m}^{2}\right)$} & \multirow{2}{*}{$\begin{array}{c}\text { No. of fat globules } \\
\text { measured }\end{array}$} \\
\hline & & Mean & S.D. & \\
\hline \multirow[t]{2}{*}{ I } & Non-sterilized & 435.79 & 604.29 & 1671 \\
\hline & Sterilized & 530.59 & 1139.58 & 2179 \\
\hline \multirow[t]{2}{*}{ II } & Non-sterilized & 386.61 & 680.99 & 1875 \\
\hline & Sterilized & 360.44 & 369.77 & 1515 \\
\hline \multirow[t]{2}{*}{ III } & Non-sterilized & 491.43 & 536.51 & 3564 \\
\hline & Sterilized & 660.19 & 1649.48 & 3353 \\
\hline \multirow[t]{2}{*}{ IV } & Non-sterilized & 202.92 & 647.38 & 2288 \\
\hline & Sterilized & 270.17 & 533.99 & 2193 \\
\hline
\end{tabular}

The statistical analysis based on the non-parametric Wilcoxon test gave similar results at the same significance level $(p<0.01)$.

In order to find whether further heat sterilization treatment brought up changes in fat globule size (area) distribution in processed cheese samples, we used a comparison of percent occurrence of small fat globules in individual samples. We regarded as small fat globules those objects that did not exceed 500 or $100 \mu \mathrm{m}^{2}$ in area. The data are summarized in Table 4. Fat globule counts were always ascertained for the same area, therefore total fat globule counts in samples with different heat treatments ( $\mathrm{N}$ and $\mathrm{S}$ ) could be compared. In the sterilized samples (S), relative counts $(\%)$ were always decreased.

Table 4. Comparison of samples - distribution and size of fat globules in the samples

\begin{tabular}{|c|c|c|c|c|c|c|}
\hline \multicolumn{2}{|c|}{ Samples } & \multirow{2}{*}{ Total } & \multicolumn{2}{c|}{ Up to $100 \mu \mathrm{m}^{2}$} & \multicolumn{2}{c|}{ Up to $500 \mathrm{~m}^{2}$} \\
\cline { 3 - 7 } & & & No. of globules & $\%$ & No. of globules & $\%$ \\
\hline \multirow{3}{*}{ I } & $\mathrm{N}$ & 1671 & 224 & 13.41 & 1251 & 74.91 \\
\cline { 2 - 7 } & $\mathrm{S}$ & 2179 & 102 & 4.68 & 1588 & 72.91 \\
\hline \multirow{3}{*}{ II } & $\mathrm{N}$ & 1875 & 580 & 30.95 & 1457 & 77.75 \\
\cline { 2 - 7 } & $\mathrm{S}$ & 1515 & 299 & 19.75 & 1168 & 77.15 \\
\hline \multirow{2}{*}{ III } & $\mathrm{N}$ & 3564 & 107 & 3.00 & 2463 & 69.13 \\
\cline { 2 - 7 } & $\mathrm{S}$ & 3353 & 260 & 7.76 & 2013 & 60.05 \\
\hline \multirow{2}{*}{ IV } & $\mathrm{N}$ & 2288 & 705 & 30.83 & 2165 & 94.67 \\
\cline { 2 - 7 } & $\mathrm{S}$ & 2193 & 393 & 17.93 & 1919 & 87.55 \\
\hline
\end{tabular}

$\mathrm{N}$ : non-sterilized, S: sterilized

\section{Discussion}

Developing computer technologies have spread throughout people's lives and are used in most fields of scientific research. At present, the importance and interest in the use of computer controlled image analysis is growing because it facilitates obtaining quantitative characteristics from images and their objective explanation. Computerized image analysis 
is a non-destructive method that allows repeated measurements. The advantages include promptness, accuracy and easy sample preparation (Zikmundová 1996).

Final structure of processed cheese is influenced by several factors such as the fat content, $\mathrm{pH}$ (Marchesseau et al. 1997), the method of mechanical processing (Klostermeyer and Buchheim 1988) and the emulsifying agents used (Sutheerawattananonda et al. 1997). In this study, each group included samples of the same chemical composition prepared in the same manner (within each group, the melted mass from one batch was divided into two parts). We therefore assume that heat treatment affects the shape of fat particles in processed cheese, however, an unequivocal conclusion regarding a direction of fat globule deformation cannot be drawn.

The size of fat globules in milk is affected by a number of intravital factors. The size of fat particles in milk products depends on technological processing variables and the ingredients used. For instance, B owland and Foegeding (2001) and Awad et al. (2002) studied the size of fat globules. The size of fat particles was usually assessed depending on some indices of technological process ( $\mathrm{pH}$, revolutions per minute, emulsifying agents used) or put in the context of rheological properties of processed cheeses. The basis for determining the size is not always the same: some researchers measured the area and even the diameter of fat globules (Bowland and Foegeding 2001), others the diameter only (Sutheerawattananonda et al. 1997).

In all the samples we investigated, fat globules were divided into groups according to their size. Table 4 shows that there was a higher proportion of small globules (up to $100 \mu \mathrm{m}^{2}$ ) in the non-sterilized samples, and due to sterilization, a proportion of large fat globules increased. During the sterilization treatment of processed cheese, small fat globules probably merge, resulting in a decrease in their counts and an increase in the area of individual objects.

The statistical analyses showed that in the processed cheese samples under investigation changes in fat globule shape occurred due to heat sterilization. Nevertheless, the data obtained did not unequivocally imply the trend of change in the fat globule shape. However, the heat treatment influenced the size of fat globules. By comparing samples subjected to different heat treatments we found out that after sterilization there were lower counts of small fat globules, which concurrently lead to higher counts of larger fat globules. Therefore, it can be assumed that during further heat treatment of processed cheese the small particles probably merge, thereby increasing their area.

The above-described procedure, based on the computer analysis of microscope images can be used to examine other foods.

\section{Vliv sterilace na velikost a tvar tukových kuliček $v$ modelových tavených sýrech}

Modelové vzorky sýrů ze 4 nezávislých výrob byly po procesu tavení a uzavření do obalů následně ošetřeny sterilačním záhřevem $\left(117^{\circ} \mathrm{C}\right.$ po dobu 20 minut $) \mathrm{s}$ cílem prodloužit dobu jejich trvanlivosti. Cílem práce byla aplikace metody obrazové analýzy na posouzení změny velikosti a tvaru tukových kuliček vlivem sterilačního záhřevu. Součástí práce byl také výběr vhodného postupu pro přípravu mikroskopických preparátů, zhotovení mikrofotografií a šablony pro automatické zpracování snímků obrazovým analyzátorem, zjištění parametrů pro určení velikosti a tvaru tukových kuliček a statistické zpracování výsledků.

Na základě provedeného experimentu lze dojít k názoru, že změna tvaru tukových kuliček v důsledku sterilačního záhřevu není jednoznačná. Na druhou stranu bylo zjištěno, že vlivem termosterilačního ošetření $\left(117^{\circ} \mathrm{C}\right.$ po dobu 20 minut) se velikost tukových kuliček signifikantně zvýšila $(p<0,01)$, což bylo doprovázeno snížením podílu menších tukových kuliček (do $500 \mu \mathrm{m}^{2}$, resp. do $100 \mu \mathrm{m}^{2}$ ) ve vzorcích sterilovaných tavených sýrů. Z výsled- 
ků rovněž vyplývá, že metoda analýzy obrazu je plně využitelná při posuzování vlivu technologického procesu na jakost tavených sýrů.

\section{Acknowledgments}

The present study was supported by the Ministry of Education, Youth and Sports, the Research Project No. 6215712402 (Veterinary aspects of food safety and quality).

\section{References}

AGRESTI A 1984 Analysis of ordinal categorical data. John Wiley \& Sons, Inc.USA, 287 p.

AWAD RA, ABDEL-HAMID LB, EL-SHABRAWY SA, SINGH RK 2002: Texture and microstructure of block type processed cheese with formulated emulsifying salt mixtures. Lebensm - Wissensch Technol 35: 54-61

BIJKER PGH, KOOLMEES PA, van LOGTESTIJN JG 1983 Tissue composition of mechanically deboned pork (MDP). Meat Sci 9: 257- 269

BOWLAND EL, FOEGEDING EA 2001 Small strain oscillatory shear and microstructural analysis of a model processed cheese. J Dairy Sci 84: 2372-2380

BYLUND G 1995: Dairy Processing Handbook. Lund: Tetra Pak Processing Systems, 436 p.

CACCAMO M, MELILLI C, BARBANO D M, PORTELLI G, MARINO G, LICITRA G 2004: Measurement of gas holes and mechanical openness in cheese by image analysis. J Dairy Sci 87: 739-748

CARIĆ M, KALÁB M 1997: Processed cheese products. In Fox, P.F. (Ed.) Cheese: Chemistry, Physics and Microbiology. Volume 2. Major Cheese Groups, 2. ed. Elsevier Applied Science, London and New York, pp. 467-505

GUINEE TP 2003 Pasteurized processed cheese products. In Roginski, H., Fuquay, J.W., Fox, P.F. (Eds) Encyclopedia of Dairy Science, Volume 1. London: Elsevier Science, pp. 411-418

HEERTJE I, LEUNIS M 1997 Measurement of shape and size of fat crystals by electron microscopy. Lebensm Wissensch Technol 30: 141-146

HILDEBRANDT G, HIRST L 1985 Determination of the collagen, elastin and bone content in meat products using television image analysis. J Food Sci 50: 568-570

HOLCOMB DN, PECHAK DG, CHAKRABATI S, OPSAHL A 1992: Visualizing textural changes in dairy products by image analysis. Food Technol 46: 122-127

KLOSTERMEYER H, BUCHHEIM, W 1988: Die Mikrostruktur von Schmelzkäseerzeugnissen. Kieler Milchwirtschaftliche Forschungsberichte 40: 219-231

MAFART P, COUVERT O, LEGUÉRINEL I 2001: Effect of pH on the heat resistance of spores. Comparison of two models. Int J Food Microbiol 63: 51-56

MARCHESSEAU S, GASTALDI E, LAGAUDE A, CUQ J 1997: Influence of pH on protein interactions and microstructure of process cheese. J Dairy Sci 80: 1483-1489

PALKA K, DAUN H 1999 Changes in texture, cooking losses and myofibrilar structure of bovine $M$. semitendinosus during heating. Meat Sci 51: 237-243

RAVAL DM, MISTRY VV 1999: Application of ultrafiltered sweet buttermilk in the manufacture of reduced fat process cheese. J Dairy Sci 82: 2334-2343

SUTHEERAWATTANANONDA M, FULCHER RG, MARTIN FB, BASTIAN ED 1997 Fluorescence image analysis of process cheese manufactured with trisodium citrate and sodium chloride. J Dairy Sci 80: 620-627

STANDARDISATION AGREEMENT (STANAG) 2937 2001: Survival, Emergency and Individual Combat Ration - Nutritional Values and Packaging. 3. ed. Brussels: NATO/MAS

TREMLOVÁ B, ŠTARHA P 2002: Histometric evaluation of meat products - determination of size and number of objects. Czech J Food Sci 20: 175-180

YOON WB, McCARTHY KL 2003: Flow behavior of processed chesee melts. J Food Process Engineering 26: 559-576

WANG HH, SUN DW 2002 Melting characteristic of cheese: analysis of effects of cooking conditions using computer vision technology. J Food Engineering 51: 305-310

WANG HH, SUN DW 2003: Assessment of cheese browning affected by baking conditions using computer vision. J Food Engineering 56: 339-345

ZIKMUNDOVÁ M 1996: The use of image analysis for food quality evaluation. Master Thesis. Institute of Chemical Technology, Prague, 98 p. (in Czech) 
Plate V

Tremlová B. et al.: The Effect of Sterilization ... pp. 419-426

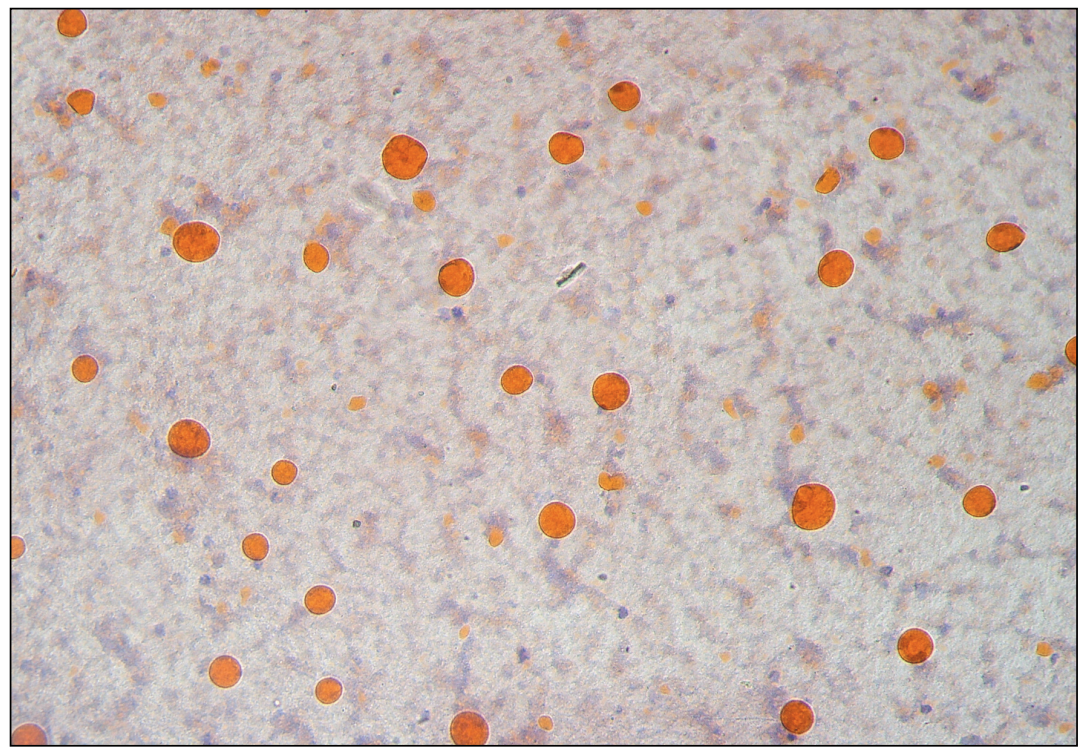

Fig. 1. Fat globules stained with Oil Red. 